\title{
On improving the efficiency of blasting operations in underground and open-pit mining
}

\author{
Oleksii Kyrychenko ${ }^{1}$, Anton Kurliak ${ }^{1 *}$, Oleh Balakin ${ }^{1}$, Oleksandr Baskevych ${ }^{2}$ \\ ${ }^{1}$ State Enterprise "Research-Industrial Complex "Pavlograd Chemical Plant", 44 Zavodska St., 51402 \\ Pavlohrad, Ukraine \\ ${ }^{2}$ Ukrainian State Chemical Technology University, Department of Inorganic Substances and Ecology, \\ 8 Haharina Ave., 49005 Dnipro, Ukraine
}

\begin{abstract}
The purpose is to study the effect of microstructure defects of initiating explosives on the process of initiating detonation by a laser monopulse. The results of experimental studies and physico-mathematical modeling of the effect of microstructural defects in crystals of photosensitive initiating explosives under the action of a single laser pulse are given. The paper covers a brief analysis of the history of the issue being studied and physico-mathematical modeling using the theory of elastic scattering, i.e. Gustav Mie theory. The technique for determining the absorption cross section of laser radiation by micro-sized inclusions of explosive has been developed and tested. In experiments on explosives ignition using a laser monopulse, the laser monopulse shape was recorded, the energy distribution over the laser beam radius and the explosive ignition delay time were controlled. The basis is the proposed method of calculating the absorption cross section and intensity in terms of the laser radiation wavelength by the inclusion of an explosive with using the theory of elastic scattering of optical radiation on particles in micrometer size range. It is shown that the absorption properties of the particle essentially depend on the properties of the particle medium and the wavelength of radiation. For smoke particle within PETN the absorption for wavelength of laser radiation of $1.06 \mu \mathrm{m}$ is stronger than for that of $0.69 \mu \mathrm{m}$. A different absorption occurs if a lead particle is within a lead azide: absorption for wavelength of $0.69 \mu \mathrm{m}$ is twice as strong as for wavelength of $1.06 \mu \mathrm{m}$. During the manufacture of explosives the additional defects in the explosives microstructure are desired to be created to increase the efficiency of laser initiation. Findings are used in the development of technical specifications for the design of optical detonators for laser initiation systems.
\end{abstract}

\section{Introduction}

In the mining industry, explosive energy utilization is one of the most common methods for the rock destruction and an integral part of the technological process of mining. As a rule, for effective destruction of rocks and improve the blasting safety, various designs of

\footnotetext{
*Corresponding author: anton.kurlyak@yandex.ru
} 
borehole and blast-hole charges as well as explosives with new formulations that provide the minimum yield of harmful gases in detonation products are used. However, at the same time, two methods of blasting charges dominate: non-electric one (NONEL type), which is used for the open-cast mining, and electric method is mainly used in coal mines. While there are continuous improvements in those areas, then no changes occur in the use of primary initiating explosives. It is the primary explosives in blasting supplies and the presence of high-energy components in the firing circuit that determine the safety level of any system for initiating explosive charges.

High energy indicators of advanced explosives for borehole and blasthole charges are characterized by stable operational, explosive, chemical and physical indicators and, in general, utterly meet the practical requirements.

Thus, the problem lies in the primary initiating explosives, characterized by high sensitivity to external physical influences, low level of safety in the manufacture, storage and use. Some gases in the detonation products of primary explosives are harmful, have a significant negative effects on the environment and the human body. Large-scale blasting increase adverse impact.

The switch to the exploitation of advanced initiating explosive charges, such as laser initiation, for example, will provide a high level of safety, high accuracy of short-delayed blasting and absolute resistance to external electromagnetic effects. New explosives equipped with primary photosensitive explosive composites can provide such a leap in technological capabilities.

Transparency for laser radiation is one of the most important physical properties of initiating explosives in research. Some regularities of laser radiation to transparent dielectrics interaction occur upon explosives exposure to light $[1-3]$.

A typical effect of the laser pulse on transparent substances is the material destruction with resulting cracks and cavities. It has been established that crystal defects and inclusions are responsible for the destruction of commonly used optical materials. The presence of vacancy clusters, impurities, dislocations in the dielectric crystal lattice significantly disturbs the band structure, which leads to focal substance heating and its destruction. The influence of structural defects on substance destruction confirms that the threshold for surface damage is lower than that for the bulk damage. The structure of the substance surface layer has a significantly higher defect density in comparison with the crystal volume [4]. According to [4] the surface layer defects have a size of 3 to $5 \mu \mathrm{m}$ and the absorption index is about $10^{2} \mathrm{~cm}^{-1}$.

Studies of the defective structure of glass, ruby and other transparent dielectrics were carried out using the light scattering and electronic microscopy methods. The method of ultramicroscopy using a He-He-laser [5] made it possible to detect highly scattering areas of $\sim 100 \mathrm{~nm}$ and decorated block boundaries of $\sim 70 \mathrm{~nm}$. The evaluations given in work [6] show that the absorption index of these inclusions is of the order of $10^{4} \mathrm{~cm}^{-1}$.

Investigations of the absorbing inclusion characteristics using a nonlinear scattering showed that in purified glass the size of inclusions is $0.2-0.3 \mu \mathrm{m}$ and the absorption index is $8 \cdot 10^{2} \mathrm{~cm}^{-1}$ [3]. The analysis of the experimental results of the polymers laser destruction found that the absorption index of optical microscopic inhomogeneities is in the range of $10^{2}-10^{3} \mathrm{~cm}^{-1}$ [7]. A specific mechanism for generation of absorbing inclusions in a dielectric matrix is proposed in work [8].

The authors of the cited papers refer the presence of inclusions like smoke and metal particles in polymers [9] and explosives like TNT, hexogen and octogen [10] - to atmospheric aerosols entering the material; their sizes make a value of $10^{-5}-10^{-4} \mathrm{~cm}[11]$.

Works $[12-14]$ show that the silver azides and lead azides, when exposed to radiation by a flow of electrons, ultraviolet radiation, heating or pressing - are partially decomposed to generate the metallic nuclei. According to [1], the size of the nuclei can reach $\sim 10^{-5} \mathrm{~cm}$. 
Lead styphnate have been examined by optical microscopy [15]. It is shown that this substance contains inclusions of $1-10 \mu \mathrm{m}$ size, which concentrations amount to $2.5 \cdot 10^{6} \mathrm{~cm}^{-3}$. According to the evaluations given in the work, the absorption index of these inclusions is of the order of $4 \cdot 10^{3} \mathrm{~cm}^{-1}$.

Thus, the experimental data presented show that the commonly used transparent substances, including explosives, are optically inhomogeneous materials. Moreover, the nature of microinhomogeneities is determined both by the physical characteristics of this substance and the method of its preparation.

In the 1960s of the last century, the phenomenon of ignition of explosives by laser radiation was experimentally found, the history of which and its physical characteristics are described, for example, in [16 - 19]. Studies of the initiation of detonation were carried out using standard initiating explosives. The most attention was paid to lead trinitroresorcinate (TNRS), lead azide and silver azide [20-22]; among the secondary explosives, the pentaerythritol tetranitrate (PETN) [23 - 25] have been thoroughly studied and is being studied, while hexogen and octogen - to a lesser extent.

Works [26-27] studied respectively the illumination pattern in a volume of explosive and the effect of absorbing impurities on the explosives ignition mechanism, with paying attention to the problems of kinetics and the explosives decomposition mechanism [28]. Based on the modern concept, within which the requirements for primary explosives [18] are imposed, no new properties could be found. Primary explosives were extremely sensitive to mechanical and thermal effects, dangerous to handle, and were characterized by low power. For these reasons their use in laser systems was inappropriate. To create a new initiation system, primary explosives with high photosensitivity were required $[17,18]$. In addition, new generations of technologies in mechanical engineering, space industry, geophysics and mining required the new technical means and materials to ensure entirely efficient and safe materials treatment by explosion [29-33].

Since the results of study of standard initiating explosives did not comply with the physico-technical characteristics and energy considerations, Prof. M. Ilyushin and his colleagues synthesized a series of photosensitive energy-saturated composites, i.e. primary explosives of a new class [34-36] for laser system initiating devices [37, 38]. The need for such studies is caused by the creation of relatively safe to handle (with PETN sensitivity) primary initiating explosives.

Currently the laser initiation of explosive charges is used at the enterprises of the machine-building and mining and metals sector, in the pyroautomatics of spacecraft, vehicles and other equipment [16-19]. The requirement for good practice is to create a precision and the most reliable initiation system which is safe to any external electromagnetic influences and surpasses the functionality of famous world patterns [37]. Of particular importance are the studies to create such initiation systems that can be used most effectively to conduct mass explosions in underground mining of coal and shale [39]. Achievement of this result will be possible in case of the synthesis of primary explosives, characterized by high photosensitivity, power, relative safe handling and sensitivity to thermal and various mechanical effects.

The relevance of the research is to study the physical processes occurring during laser heating of optical microinhomogeneities (defects of the crystal microstructure, impurities) to substantiate the mathematical model of focal ignition of composites which are photosensitive to laser initiation and to design new explosives for laser initiation systems.

The purpose of the study is the development and testing of a method for determining the absorption cross section of laser radiation by micro-size inclusion, taking into account the theory of elastic scattering of optical radiation on spherical particles in micrometer size range. 


\section{Research methods}

Experimental studies were conducted using the technique described in [38]. A neodymium laser with a wavelength of $1.06 \mu \mathrm{m}$ was used as well as a ruby laser with a wavelength of $0.69 \mu \mathrm{m}$ generating a monopulse (design of the Dnipro University of Technology [37]). Samples of lead azide, phlegmatized with $20 \%$ addition of polymethyl methacrylate, and synthesized photosensitive explosive composites were used as energy-saturated materials. Properties of synthesized photosensitive explosive composites were studied in [34, 35].

When conducting theoretical studies, a complete solution of Maxwell's equations was used to determine the regularities of scattering of electromagnetic waves on spherical particles i.e. the Mie theory.

The shape of the laser pulse is shown in Fig. 1. The characteristic time of the pulse rise and fall is $10^{-10} \mathrm{~s}$. The signal from the photodiode was recorded with a Tektronix SCD1000 oscilloscope. The maximum input frequency is $1 \mathrm{GHz}$; the laser full width at half intensity is $\mathrm{Dt}=10.99707 \mathrm{~ns}$.

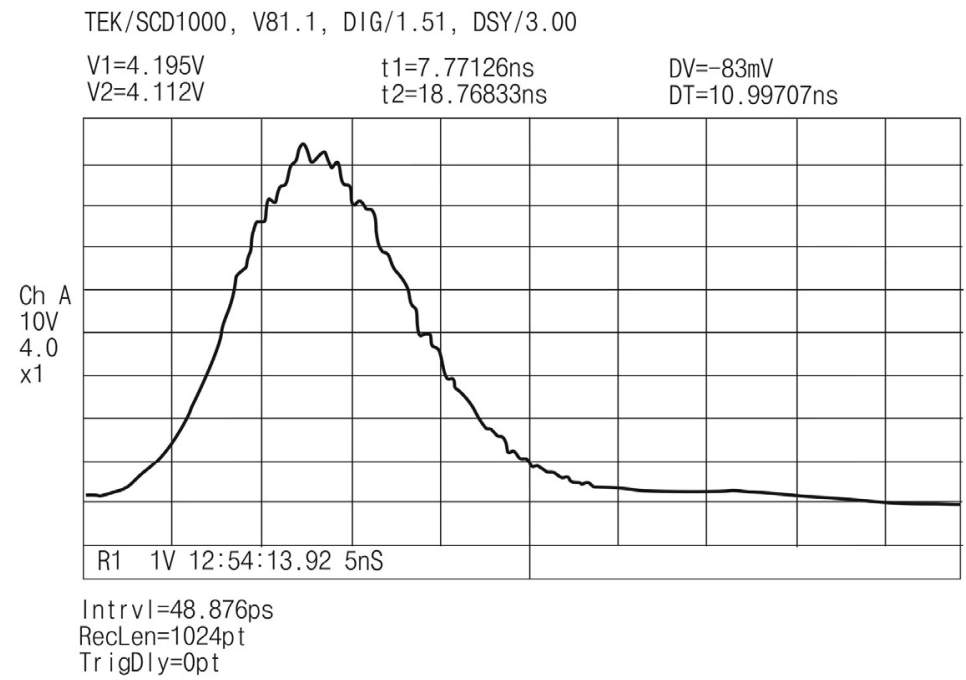

Fig. 1. Laser monopulse shape. Laser beam diameter $-2.34 \mathrm{~mm}$.

When determining explosion delay time relative to a laser pulse in the course of the experiments, a single photodiode was used, which recorded both a laser pulse and a light pulse from the products of explosion. A typical oscillogram is shown in Fig. 2.

The first peak on the left corresponds to laser pulse, and the second peak on the right corresponds to the maximum of light radiation from the products of explosion. When using a dual-channel record scheme by means of two photodiodes, the results were similar.

Fig. 3 shows the peculiarities of energy distribution along laser beam radius using Silicon Camera (Model LBA-100F). 


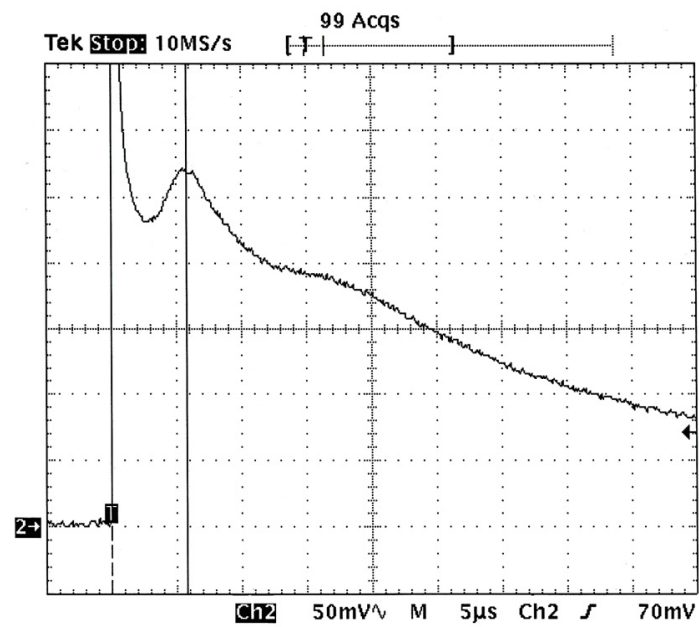

Fig. 2 Oscillogram of record of ignition delay time of $\mathrm{BaNClO}_{3}+10 \%$ PMVT-3M relative to a laser pulse. Detonation initiation delay is $31 \mu \mathrm{s}$.

$a$

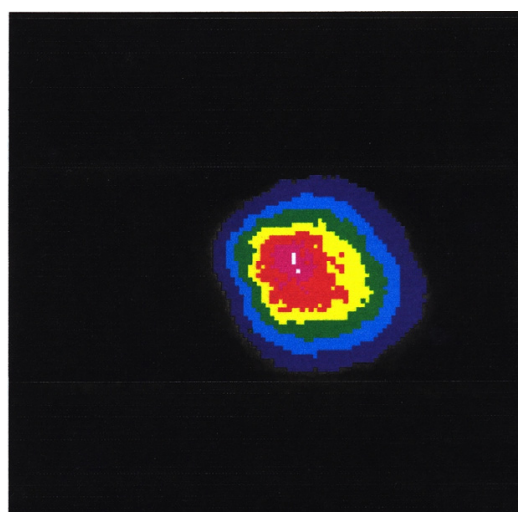

$b$

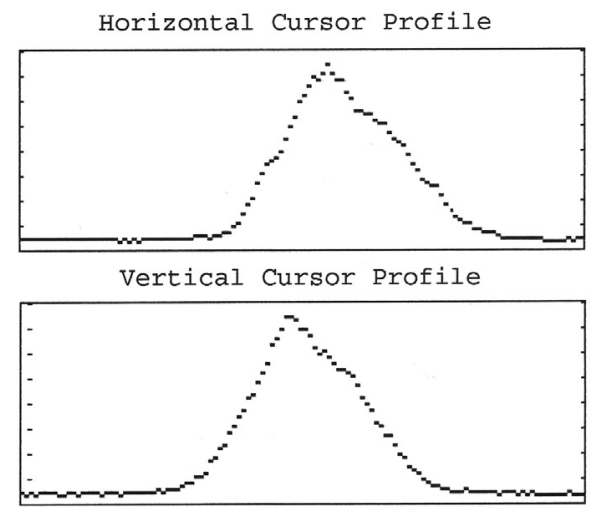

Fig. 3. Example of distribution of energy density over the cross section of a laser beam (beam diameter is $2.35 \mathrm{~mm}$ ).

\section{Research results and their discussion}

To solve the problem of laser initiation of explosive charges, first of all, it is necessary to determine the temperature fields in the inclusion-matrix system, the calculation accuracy of which is determined by the correct setting of the rate of energy release in the absorbing inclusion. For this, it is necessary to set the value of the absorption cross-section accurately enough. The solution of this question, in our opinion, is possible within the framework of the theory of light scattering by a spherical particle developed by Gustav Mie (Mie theory) $[40,41]$.

According to this theory, the radiation scattered by a particle is represented by superposition of fields - multipoles induced by an incident wave in the particle. Mathematically, this is expressed by a convergent series of oscillating functions depending on the diffraction parameter: 


$$
x=\frac{2 \pi r_{0}}{\lambda}
$$

and complex refractive index of $m=n-i$.

Where $r_{0}$ is a particle radius, $m$ and $æ$ are refractive and attenuation indices at laser radiation wavelength $\lambda$.

It is convenient to carry out calculations not for cross-sections, but for their dimensionless analogs that is efficiencies of the corresponding processes:

$$
Q=\frac{\sigma}{\sigma_{g}}
$$

where $\sigma$ is process cross-section, $\sigma_{g}=\pi r^{2}$ is geometrical cross-section for a spherical particle. These series are as follows [41]:

For scattering efficiency:

$$
Q_{s}=\frac{2}{x^{2}} \sum_{z=1}^{\infty}(2 z+I)\left(\left|a_{z}\right|^{2}+\left|b_{z}\right|^{2}\right) .
$$

For attenuation efficiency:

$$
Q_{t}=\frac{2}{x^{2}} \sum_{z=1}^{\infty}(2 z+I) \operatorname{Re}\left(a_{z}+b_{z}\right) .
$$

For absorption efficiency:

$$
Q_{a}=Q_{t}+Q_{s}
$$

The dependence of $Q$ on $x$ and $m$ lies in special functions $a_{z}(x, m)$ and $b_{z}(x, m)$ which are Mie coefficients:

$$
\begin{aligned}
& a_{z}=\frac{\varphi_{z}(x) \varphi_{z}^{\prime}(y)-m \varphi_{z}(y) \varphi_{z}^{\prime}(x)}{\xi_{z}(x) \varphi_{z}^{\prime}(y)-m \varphi_{z}(y) \xi_{z}^{\prime}(x)} \\
& b_{z}=\frac{m \varphi_{z}(x) \varphi_{z}^{\prime}(y)-\varphi_{z}(y) \varphi_{z}^{\prime}(x)}{m \xi_{z}(x) \varphi_{z}^{\prime}(y)-\varphi_{z}(y) \xi_{z}^{\prime}(x)}
\end{aligned}
$$

Where $y=m x$; a stroke denotes the derivative with respect to the corresponding argument, $\varphi_{z}$ and $\xi_{z}$ are Ricatti-Bossel functions, defined by the recurrence relations [42]

$$
\begin{aligned}
& W_{z+1}=\frac{2_{z}+I}{Z} W_{z}(z)-W_{z-1}, \\
& W_{z}^{\prime}(z)=-\frac{Z}{Z} W_{z}(z)-W_{z-1}(z) .
\end{aligned}
$$

Functions $\varphi_{z}$ and $\xi_{z}$ has the following property: $\varphi_{z}(x)=\operatorname{Re} \xi_{z}(x)$ for real $x$.

The first two values of the function required to apply recurrent formulas (4), (5) are as follows:

$$
W_{0}(x)=\sin x+i \cos x ; \quad W_{-1}(x)=\cos x i+i \sin x .
$$

The use of recurrent formulas for calculating $a_{z}$ and $b_{z}$ leads to a number of difficulties noted in [43], namely, there is an accumulation of errors when calculating decreasing 
functions, which entails obtaining "correct" but physically meaningless results (the scattering cross section becomes larger than the attenuation cross section). The literature describes methods to avoid this. They are based on the use of continued fractions, or on the application to calculate the real and imaginary parts of $\xi$, for two different recurrent formulas [44]. As the results of our software implementation show, their use is justified in calculations for very large ones.

Following the method proposed in [41], we introduce a logarithmic derivative:

$$
D_{z}=\frac{\varphi_{z}^{\prime}(y)}{\varphi_{z}(y)} .
$$

Using (5), we obtain a recurrence formula

$$
\left(D_{z}(y)+\frac{z}{y}\right)\left(D_{z-1}(y)-\frac{z}{y}\right)=-I .
$$

Hence, the ascending recurrence is:

$$
D_{z}(y)=-\frac{z}{y}\left(D_{z-1}(y)-\frac{z}{y}\right)^{-1} .
$$

From (5) and (6) we obtain the initial value $D_{0}=\operatorname{ctg} y$ and the asymptotic value for large $|y|: D_{0} \approx 0+i$.

From (3), applying (4), (5) and (7), we obtain expressions for Mie coefficients [40]:

$$
\begin{gathered}
a_{z}=\frac{\left(\frac{D_{z}(y)}{m}+\frac{z}{x}\right) \operatorname{Re} W_{z}(x)-\operatorname{Re} W_{z-1}(x)}{\left(\frac{D_{z}(y)}{m}+\frac{z}{x}\right) W_{z}(x)-W_{z-1}(x)} ; \\
b_{z}=\frac{\left(\frac{D_{z}(y)}{m}+\frac{z}{x}\right) \operatorname{Re} W_{z}(x)-\operatorname{Re} W_{z-1}(x)}{\left(\frac{D_{z}(y)}{m}+\frac{z}{x}\right) W_{z}(x)-W_{z-1}(x)} .
\end{gathered}
$$

A computer program was developed to calculate these coefficients and efficiencies. In order to avoid the accumulation of errors noted above, variables of double precision were consistently used, so the difficulties noted by Dayrmendzhan did not appear even with relatively large particle sizes $(x \sim 200 \mu \mathrm{m})$. The summation in series $(1),(2)$ was carried out till:

$$
\frac{(2 z+I)\left(\left|a_{z}\right|^{2}+\left|b_{z}\right|^{2}\right)}{\sum_{k-1}^{z-1}(2 k+I)\left(\left|a_{k}\right|^{2}+\left|b_{k}\right|^{2}\right)} \leq \varepsilon
$$

or

$$
\frac{(2 z+I) \operatorname{Re}\left(a_{z}+b_{z}\right)}{\mid \sum_{k-1}^{z-1}(2 k+I) \operatorname{Re}\left(a_{k}+b_{k}\right)} \leq \varepsilon
$$


At $\varepsilon=10^{-4}$ it was necessary to take into account $z \cong x=10$ terms of series.

For particles in a material medium, the value of $m$ has the meaning of the relative complex refractive index $m=m_{0} / n_{0}$, where $n_{0}$ is the value of the refractive index averaged over optical axes.

This method is used in calculations of current research to determine cross section of absorption of metallic inclusions found in metal azides, as well as absorption cross section of a soot particle in PETN at wavelengths of 0.69 and 1.06 microns.

For a lead particle

$$
\begin{gathered}
m_{0}=1.19-2.15 i, \lambda=0.6 \mu \mathrm{m}, \\
m_{0}=0.86-3.33 i, \lambda=1.06 \mu \mathrm{m} .
\end{gathered}
$$

For a soot particle

$$
\begin{aligned}
& m_{0}=1.28-0.41 i, \lambda=0.69 \mu \mathrm{m}, \\
& m_{0}=2.5-i, \lambda=1.06 \mu \mathrm{m},[29] .
\end{aligned}
$$

For lead azide $n_{0}=1.85$, for PETN $n_{0}=1.6$ [44].

Figs. 4 and 5 show the results of calculations of dependence of absorption efficiency (dependence of absorption cross section) on the diffraction parameters of soot and lead particles, respectively, in the air and in the explosive matrix, when exposed to radiation of neodymium and ruby lasers.

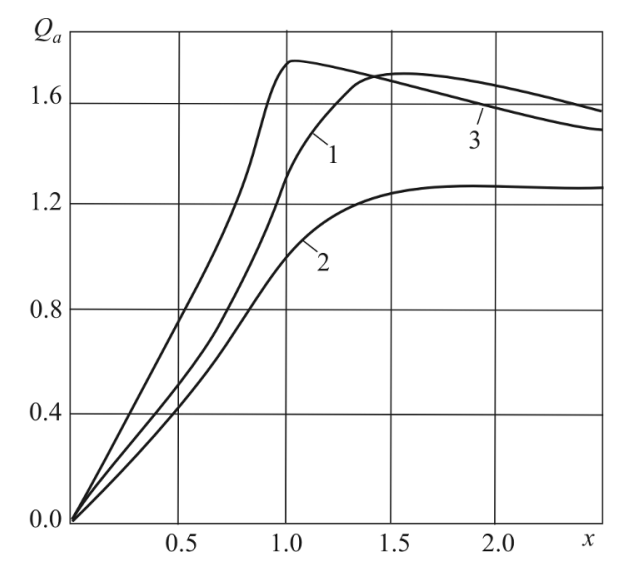

Fig. 4. Dependence of radiation absorption cross section on the diffraction parameter on a soot particle: 1 - a particle in PETN, radiation wave length of $1.06 \mu \mathrm{m} ; 2$ - a particle in PETN, radiation wavelength of $0.69 \mu \mathrm{m} ; 3$ - a particle in the air.

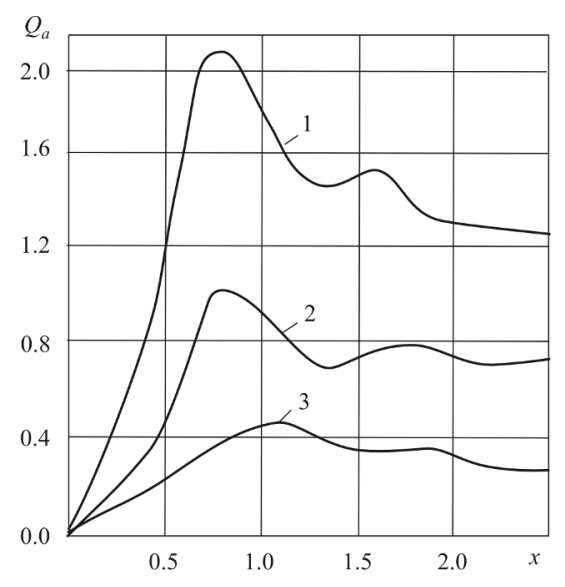

Fig. 5. Dependence of radiation absorption cross section on the diffraction parameter on a lead particle: 1 - a particle in lead azide; radiation wavelength of $0.69 \mu \mathrm{m} ; 2$ - a particle in vacuum; radiation wavelength of $1.06 \mu \mathrm{m} ; 3$ - a particle in the air.

\section{Conclusions}

Absorption properties of a particle essentially depend on the properties of the medium in which this particle is located, as well as on radiation wavelength. For a soot particle, located in PETN, the absorption at a wavelength of laser radiation of $1.06 \mu \mathrm{m}$ is stronger than for radiation with a wavelength of $0.69 \mu \mathrm{m}$. A different absorption pattern can be seen if a lead particle is in lead azide: absorption at a wavelength of $0.69 \mu \mathrm{m}$ is twice as strong as at a wavelength of $1.06 \mu \mathrm{m}$. According to Figs. 4 and 5 the intensity of light absorption 
by a particle is affected by the electrical conductivity of the containing medium and the energy of laser radiation.

The proposed method of calculating the optical characteristics of microinclusions was used to determine absorption cross section in metal azides at the wavelengths of neodymium and ruby lasers in order to select the most efficient radiation source for reliable initiation of any given primary explosives. When studying the sensitivity of a methane-air mixture to ignition, laser initiation was used to initiate safety emulsion explosives of $4^{\text {th }}$ class in an experimental mine tunnel [45]. The research results are used in the development of technical specifications for the design of optical detonators for laser initiation systems.

The authors are grateful to the staff members of Dnipro University of Technology for helpful advice and feedback and to the managers of the Pavlograd Chemical Plant for the opportunity to conduct experimental research.

\section{References}

1. Mirkin, L.I. (1975). Fizicheskie osnovy obrabotki materialov luchami lazera. Moskva: Izdatel'stvo Moskovskogo gosudarstvennogo universiteta.

2. Danileyko, Yu.K., Manenkov, A.A., Prokhorov, A.M., \& et al. (1978). Poverkhnostnoe razrushenie lazernykh kristallov rubina. Trudy Fizicheskogo Instituta Akademii Nauk SSSR, (101), 9-31.

3. Danileyko, Yu.K., Manenkov, N.A., \& Nechitaylo, V.S. (1978). Issledovanie ob'emnogo lazernogo razrusheniya i rasseyanie sveta v kristallakh i steklakh. Trudy Fizicheskogo Instituta Akademii Nauk SSSR, (101), 31-75.

4. Danileyko, Yu.K., Manenkov, A.A., Prokhorov, A.M., \& et al. Poverkhnostnoe razrushenie kristallov rubina lazernym izlucheniem. Zhurnal Eksperimental'noy i Teoreticheskoy Fiziki, 58(1), 31-36.

5. Kovalev, A.A., Makshantsev, B.I., Pilipetskiy, N.F., Savanin, S.Yu., \& Finkel'berg, V.M. (1984). Nelineynoe rasseyanie lazernogo izlucheniya i kinetika khimicheskikh reaktsiy v mikroob'emakh veshchestva. Kvantovaya Elektronika, 11(1), 119-125.

6. Nechitaylo, V.O. (1982). Mekhanizm lazernogo razrusheniya prozrachnykh polimernykh materialov. Izvestiya Akademii Nauk SSSR. Seriya Fizika, (46), 1194-1199.

7. Manenkov, A.A., Nechitaylo, V.O., \& Tsaprilov, A.O. (1981). Analiz mekhanizma lazernogo razrusheniya prozrachnykh polimerov, svyazannogo $\mathrm{s}$ ikh vyazkouprugimi svoystvami. Kvantovaya Elektronika, 8(1), 838-842.

8. Vinogradov, A.V., \& Pribel'skiy, M.I. (1979). Rol' kolloidnykh chastits v opticheskom proboe shchelochno-galloidnykh kristallov. Pis'ma v Zhurnal Tekhnicheskoy Fiziki, 5(10), 595-598.

9. Orlov, A.A., \& Ulyakov, P.I. (1976). Mekhanizm obrazovaniya vysokotemperaturnogo ochaga pri lazernom razrushenii prozrachnykh polimerov. Prikladnaya Mekhanika i Tekhnicheskaya Fizika, (1), 127-133.

10. Otrakovskiy, L.G. (1985). Ob ochagovom mekhanizme zazhiganiya nekotorykh vtorichnykh vzryvchatykh veshchestv monokhromatichnym svetovym impul'som. Fizika Goreniya i Vzryva, 21(1), 41-44.

11. Zuev, V.E. (1970). Rasprostranenie vidimykh $i$ infrakrasnykh voln $v$ atmosfere. Moskva: Sovetskoe radio.

12. Bouden, F., \& Ioffe, A. (1962). Bystrye reaktsii v tverdykh telakh. Moskva: Inostrannaya literatrura.

13. Aleksandrov, E.I., \& Tsipilev, V.P. (1982). Vliyanie davleniya pressovaniya na chuvstvitel'nost' azida svintsa k deystviyu lazernogo izlucheniya. Fizika Goreniya i Vzryva, 18(2), 100-103. 
14. Afanas'yev, G.T., \& Bobolev, V.K. (1968). Initsiirovanie tverdykh vzryvchatykh veshchestv udarom. Moskva: Nauka.

15. Baranovskiy, A.M. (1985). Optika i osobennosti initsiirovaniya TNRO lazernym monoimpul'som. Dnepropetrovsk: Institut tekhnicheskoy mekhaniki Arademii nauk SSSR.

16. Veyko, V.P., Libenson, M.N., Chervyakov, G.G., \& Yakovlev, E.B. (2008). Vzaimodeystvie lazernogo izlucheniya s veshchestvom (silovaya optika). Moskva: Fizmatlit.

17. Ilyushin, M.A., Tselinskiy, I.V., \& Sudarikov, A.M. (2006). Razrabotka komponentov vysokoenergeticheskikh kompozitsiy. Sankt-Peterburg: Sankt-Peterburgskiy gosudarstvenniy tekhnicheskiy universitet.

18. Ilyushin, M.A., Sudarikov, A.M., \& Tselinskiy, I.V. (2006). Metallokompleksy $v$ vysokoenergeticheskikh kompozitsiyakh. Sankt-Peterburg: Leningradskiy gosudarstvenniy universitet im. A.S. Pushkina.

19. Sazonnikova, N.A. (2013). Lazernoe initsiirovanie detonatsii vysokoenergeticheskikh veshchestv. Saarbryukken: LAP LAMBERT Academic Publishing GmbH\&CO.KG.

20. Karabanov, Yu.F., \& Bobolev, V.K. (1981). Zazhiganie initsiiruyushchikh vzryvchatykh veshchestv impul'som lazernogo izlucheniya. Doklady Akademii Nauk SSSR, 256(5), 1152-1154.

21. Aleksandrov, E.I., \& Tsipilev, V.P. (1984). Issledovanie vliyaniya dlitel'nosti vozbuzhdayushchego impul'sa na chuvstvitel'nost' azida svintsa $\mathrm{k}$ deystviyu lazernogo izlucheniya. Fizika Goreniya i Vzryva, 20(6), 104-109.

22. Medvedev, V.V., \& Tsipilev, V.P. (2006). Osobennosti lazernogo initsiirovaniya pressovannykh i nasypnykh poroshkov azida svintsa. In Energeticheskie kondensirovannye sistemy (pp. 252-253). Chernogolovka, Russia: Institut problem khimicheskoy fiziki.

23. Tarzhanov, V.I., Zinchenko, A.D., \& Sdobnov, V.I. (1996). Lazernoe initsiirovanie tena. Fizika Goreniya i Vzryva, 32(4), 113-119.

24. Karabanov, Yu.F., Afanas'yev, G.T., \& Bobolev, V.K. (1997). Zazhiganie tverdykh vtorichnykh vzryvchatykh veshchestv korotkim impul'som OKG. In Gorenie kondensirovannykh sistem. (pp. 5-8). Chernogolovka, Russia: Institut problem khimicheskoy fiziki.

25. Aduev, B.P., Nurmukhametov, D.R., \& Puzynin, A.V. (2009). Vliyanie dobavok nanochastits monokarbida nikelya na chuvstvitel'nost' tetranitropentaeritrita k lazernomu vozdeystviyu. Khimicheskaya Fizika, 28(11), 45-48.

26. Aleksandrov, E.I., \& Tsipilev, V.P. (1988). Osobennosti svetovogo rezhima v ob'eme polubeskonechnogo sloya DRS pri osveshchenii napravlennym puchkom konechnoy apertury. Izvestiya VUZov, seriya fizicheskaya, 31(10), 23-29.

27. Aleksandrov, E.I., Voznyuk, A.G., \& Tsipile, V.P. (1989). Vliyanie pogloshchayushchikh primesey na zazhiganie vzryvchatykh veshchestv lazernym izlucheniem. Fizika Goreniya $i$ Vzryva, 26(1), 3-9.

28. Korepanov, V.I., Lisitsyn, V.M., Oleshko, V.I., \& Tsipilev, V.P. (2006). K voprosu o kinetike i mekhanizme vzryvnogo razlozheniya azidov tyazhelykh metallov. Fizika Goreniya $i$ Vzryva, 42(1), 106-119.

29. Chernaj, A.V., Sobolev, V.V., Ilyushin, M.A., \& Zhitnik, N.E. (1994). The method of obtaining mechanical loading pulses based on a laser initiation of explosion of explosive coatings. Fizika Goreniya i Vzryva, 30(2), 106-111.

30. Chernai, A.V., Sobolev, V.V., Ilyushin, M.A., \& Zhitnik, N.E. (1994). Generating mechanical pulses by the laser blasting of explosive coating. Combustion, Explosion, and Shock Waves, 30(2), 239-242. https://doi.org/10.1007/BF00786134

31. Chernaj, A.V., \& Sobolev, V.V. (1995). Laser method of profiled detonation wave generation for explosion treatment of materials. Fizika i Khimiya Obrabotki Materialov, (5), 120-123.

32. Sobolev, V.V., Shiman, L.N., Nalisko, N.N., \& Kirichenko, A.L. (2017). Computational modeling in research of ignition mechanism of explosives by laser radiation. Naukovyi Visnyk Natsionalnoho HIrnychoho Universytetu, (6), 53-60.

33. Soboliev, V., Bilan, N., \& Kirichenko, O. (2014). Mechanism of additional noxious fumes formation when conducting blasting operations in rock mass. Progressive Technologies of Coal, 
Coalbed Methane, and Ores Mining, 471-477. https://doi.org/10.1201/b17547-41

34. Chernai, A.V., Sobolev, V.V., Chernaj, V.A., Ilyushin, M.A., \& Dlugashek, A. (2003). Laser ignition of explosive compositions based on di-(3-hydrazino-4-amino-1,2,3-triazole)-copper(II) perchlorate. Combustion, Explosion and Shock Waves, 39(3), 335-339. https://doi.org/10.1023/A:1023852505414

35. Sobolev, V.V., \& Usherenko, S.M. (2006). Shock-wave initiation of nuclear transmutation of chemical elements. Journal de Physique IV (Proceedings), (134), 977-982. https://doi.org/10.1051/jp4:2006134149

36. Chernai, A.V., Sobolev, V.V., Ilyushin, M.A., Zhitnev, N.E., \& Petrova, N.A. (1996). On the mechanism of ignition of energetic materials by a laser pulse. Chemical Physics Reports, 15(3), 457-462.

37. Sobolev, V.V., Chernay, A.V., \& Studinsky, N.M. OPSIN - A new system of blasthole and deephole charges blasting in explosives. In 5th - International Symposium on Mine Planning and Equipment Selection (pp. 441-443). Sao Paulo, Brazil.

38. Sobolev, V.V., Chernai, A.V., Chernai, V.A., \& Ilyushin M.A. (1997). K voprosu o razrabotke sistemy lazernogo vzryvaniya zaryadov vzryvchatykh veshchestv. In Vysokoenergeticheskie Sistemy, Protsessy i ikh Modeli (pp. 255-266). Dnipropetrovsk, Ukraine: Aktsent PP.

39. Sobolev, V.V., Ustimenko, Ye.B., Nalisko, M.M., \& Kovalenko, I.L. (2018) The macrokinetics parameters of the hydrocarbons combustion in the numerical calculation of accidental explosions in mines. Naukovyi Visnyk Natsionalnoho Hirnychoho Universytetu, (1), 89-98. https://doi.org/10.29202/nvngu/2018-1/8

40. Kyrychenko, O.L. (2018). On the influence of the density of laser beam energy on the sensitivity of explosive substances to laser radiation. Naukovyi Visnyk Natsionalnoho Hirnychoho Universytetu, (6), 48-56. https://doi.org/10.29202/nvngu/2018/7

41. Deyrmendzhan, D. (1971). Rasseyanie elektromagnitnogo izlucheniya sfericheskimi polidispersnymi chastitsami. Moskva: Mir.

42. Isimaru, A. (1981). Rasprostranenie i rasseyanie voln $v$ sluchayno neodnorodnykh sredakh. Moskva: Mir.

43. Spravochnik po spetsial'nym funktsiyam. (1979). Moskva: Nauka.

44. Naumenko, E.K., Prishivalko, A.P., \& Katseva, N.R. (1975). Optimizatsiya vychislitel'nogo algoritma zadachi o rasseyanii izlucheniya polidispersnymi sredami. Vesti Akademii Nauk BSSR. Seriya Fiziko-matematicheskie nauki, (1), 71-79.

45. Kurlyak, A.V., Sobolev, V.V., Ustimenko, E.B., \& Balakin O.A. (2018). Predokhranitel'nye emul'sionnye vzryvchatye veshchestva. Otsenka retsepturnykh faktorov vliyaniya na svoystva. Zbirnyk naukovikh prats Natsionalnoho Hirnychoho Universytetu, (5-6), 42-51. 